\title{
Den olympiske sport er ikke blot et spejl af samfundet Af Inge Kryger Pedersen
}

Med de netop afholdte Olympiske Lege i Sydney er der endnu engang slået verdensrekorder. Ikke kun i sportspræstationer. Også i antallet af repræsenterede sportsdiscipliner, deltagende sportsmænd og især -kvinder, tilstedeværende tilskuere og journalister, seere og lyttere til mediers transmissioner samt i omfanget af avissider og TV-transmissioners sendetid.

To til tre millioner mennesker overværer de olympiske begivenheder direkte i værtsbyen, og mere end 1,5 milliarder mennesker, omkring et menneske ud af hver tre på Jorden, ser eller hører hele eller dele af transmissionerne derfra. Og der er efterhånden dobbelt så mange journalister som olympiske deltagere tilstede under legene. I Sydney år 2000 var der således ifølge præsidenten for Den Olympiske Komité (IOC), Juan Antonio Samaranch, 21.000 journalister tilstede, hvor der i 1996 i Atlanta var 16.000 og i Barcelona 1992 12.000 journalister.

Hele byer forandrer infrastruktur, facader og faciliteter som værtsbyer for legene, og legenes indflydelse på såvel regionale som nationale budgetter er enorm. Udgifterne til afholdelse af De Olympiske Lege beløber sig til milliarder af dollars. Gennem legenes hundredeårige historie er der adskillige eksempler på, at politiske bevægelser eller hele regimer er blevet styrket eller destabiliseret som en følge af de olympiske begivenheder.
Hvorfor har denne mere end et hundrede år gamle opfindelse fået en sådan gennemslagskraft?

Der er naturligvis mange svar på dette spørgsmål. Den svenske socialpsykolog Johan Asplund har argumenteret for en forståelse af den olympiske sports tilblivelse i slutningen af 1800-tallet som et fors $\varnothing \mathrm{g}$ på løsning af en social krise i kølvandet på modernitetsprocessers opløsning af gængse magtstrukturer i en række europæiske landes $\varnothing$ konomiske og politiske sfærer (Asplund, 1989). Hvorledes sportens rum mere specifikt kan betragtes i sine kulturelle udformninger, efterhånden som De Olympiske Lege for alvor slår igennem som en populær verdensbegivenhed i løbet af 1900-tallet, har den amerikanske sociolog John MacAloon belyst ved sin teori om »spectacle« i moderne samfund (MacAloon, 1984). Ved en sammentænkning af Asplund og MacAloons analyser udskiller artiklen nogle af den moderne sports karakteristiske træk i forsøget på at se den olympiske sports gennemslagskraft og fascination i en samfundsmæssig sammenhæng. ${ }^{1}$

Artiklens omdrejningspunkt er en modernitetsteoretisk fortolkning af sportens sociale orden, og i et fugleperspektiv vil den olympiske sport blive fortolket som en særegen løsningsmodel for sociale og kulturelle problemstillinger i moderne samfund. ${ }^{2}$ Ovennævnte forfatteres fortolknin- 
ger vil blive perspektiveret af sportskvinders indtræden på sportens offentlige arenaer. En indtræden som de nævnte forfattere ikke har værdiget opmærksomhed. Betragtet som konkret analysegenstand kan kvinders synlige sportsdeltagelse imidlertid vise sig at være i stand til at forstærke analysernes udsagnskraft.

\section{Modernitetens mimetiske rivalitet}

Tilblivelsen af de moderne Olympiske Lege i slutningen af 1800-tallet er af Asplund blevet anskuet som en »aparte«, social opfindelse, der brød og stadigvæk bryder med det herskende samfundsliv (Asplund, 1989). Indenfor den moderne sportskonkurrences tid og rum var det muligt at afgrænse sig fra en samfundsmæssig anomi ved nøje fastsatte regler for, hvorledes rivaliserende parter kunne overgå hinanden med henblik på at finde en vinder. Den samfundsmæssige krise identificerer Asplund ved magtstrukturers opløsning i en omfattende europæisk samfundsforandring, som indledtes allerede i 1700-tallet, hvor især den franske revolution var en manifestation af problematiseringen af forudbestemte positioner med hensyn til blandt andet fag og rang.

Perioden omkring De Olympiske Leges genopståen karakteriserer Asplund ved en udbredt uvished i en række europæiske stater blandt især overklassen om økonomisk og offentlig magt og status. Magtstrukturers opløsning synliggjordes i særdeleshed i Frankrigs tredje republik i slutningen af 1800-tallet, hvor enhver position i princippet kunne erobres af hvem som helst fra hvem som helst. 1880-90'erne var skandalernes årtier i Frankrig, og en skandale, der bedst illustrerede menings- og rodløshe- den, var den såkaldte Dreyfusaffære, som med falske beskyldninger mod den jødiske kaptajn Dreyfus i 1874 for tysk spionage fremstod som en affære om ingenting.

I Asplunds argumentationsmodel tildeler han den franske filosof René Girards begreb »mimetisk rivalitet « en central rolle. Asplund antager en sammenhæng og ikke en identitet mellem sport og »mimetisk rivalitet.$^{3}$ Sport kan anskues som »mimetisk rivalitet « $\mathrm{i}$ ordenes bogstavelige betydning: »efterlikna och söka överträffa« (117). Der findes imidlertid regler i sport for, hvorledes efterligningen kan finde sted, og på hvilken måde og under hvilke omstændigheder de rivaliserende parter kan overgå hinanden. Det gør der ikke i den mimetiske rivalitet. Hvis den mimetiske rivalitet kort skal beskrives, foreslår Asplund, at vi forestiller os et reciprokt forhold mellem to personer, A og B, hvor A er B's model og rival, og det samme er B for A. A vil gerne have det, B har, men B forhindrer A i dette, og omvendt. Den ene forsøger ikke kun at tage en genstand fra den anden, men også at fjerne den anden, idet den anden overhovedet var med til at skabe en attråværdig genstand. Hvis denne situation bliver almen, befinder samfundet sig i en »mimetisk krise « (30).

Alle midler er i princippet tilladte i en mimetisk rivalitet.

»... här finns varken regler, domare eller sanktioner. En mimetisk rival erkänner sig aldrig besegrad - och blir strängt taget heller aldrig besegrad. Det är otänkbart att en mimetisk rival skulle gratulere sin segerrika motståndare. Om han gör det, så rör det sig om list och beräkning. Den mimetiska rivalitetens sinnesstämning är förgrämd, här förekommer dolkstötar i ryggen och fusk hör till ordningen.«(150-51) 
I følge Girard er genstanden for den mimetiske rivalitet sekundær eller kan efterhånden være ikke-eksisterende. Samtidig er den mimetiske rivalitet en rivalitet uden ende.

Asplund er yderst kritisk overfor Girards definition og anvendelse af begrebet »mimetisk rivalitet«, først og fremmest fordi Girard overdriver begrebets omfang til at indgå $\mathrm{i}$ en "grand theory « om den menneskelige kulturs omfang og betydning. Teorien bliver så omfattende, at Asplund mener, den gør blind. Til at illustrere begrebets begrænsninger inddrager han således sporten som et kulturelt fænomen, Girard ikke med sin - i egen selvforståelse - altomfattende teori ville kunne gøre rede for.

\section{Sporten som antitese}

Sporten fremstilles af Asplund som en antitese (118) til mimetisk rivalitet i og med, at sportens genstand, det man konkurrerer om, kan siges at udgøre en »ting «, et socialt forhold i Durkheims forstand. Sporten har altså et objekt. Endvidere har en sportslig konkurrence altid en veldefineret slutning. En sejrende må og skal udpeges, og publikum og den besejrede kan i den $\gg$ rene« konkurrence kun bifalde udfaldet. Den sejrende har ret til sin sejr, hvorimod denne ret er til evig diskussion i den mimetiske rivalitet.

Men hvorfor etableres den moderne sport i sidste halvdel af forrige århundrede? Hvorfor ikke tidligere eller senere? Hvorfor blev sporten en næsten øjeblikkelig succes efter den konstruktion, som de første moderne Olympiske Lege i Athen 1896 må siges at være? Siden sporten ikke ebbede ud men tværtimod eskalerede efter Athen 1896, kunne det tyde på, at tiden var moden for sportens udbredelse. Asplund stiller sig imidlertid ikke tilfreds med, at sporten skulle være modnet frem af sig selv. Der var ikke tale om nogen massebevægelse, der udråbte ønsker om store, organiserede sportskonkurrencer. Hvis man overhovedet kan tale om et behov, mener Asplund, at det var et behov, der »blev väckt « i slutningen af forrige århundrede.

Pierre de Coubertin og hans aristokratiske fællers initiativ til at lancere de moderne Olympiske Lege tolker Asplund som en social problemløsning af den anomi, der kan være en konsekvens af mimetisk rivalitet. I dette løsningslys skal De Olympiske Leges næsten øjeblikkelige succes også ses. Pierre de Coubertin og kredsen omkring ham var næppe bevidste om, at det var en social opfindelse, de foretog. De sværmede for arven fra Hellas og antikkens idealer, men det var ikke en nærlæsning af disse, der førte til den konkrete udformning af de moderne Olympiske Lege eller for den sags skyld var afbildet særligt præcist i idégrundlaget. ${ }^{4}$ Asplund argumenterer da også for, at idéen bag udformningen var et billede af samtiden og de samfundsmæssige problemstillinger.

I Asplunds karakteristik af den store europæiske samfundsforandring, som indledtes i 1700-tallet, opstiller han to forskellige samfundsordener med den bagtanke, at sportens væsen kan forankres i deres indbyrdes kontrast (125ff). I korte træk illustrerer han de to ordener som henholdsvis en vertikal og en horisontal katedral med tid og rum som grunddimensioner. Den vertikale orden er i sin høje og smalle form tidløs og illustrerer en lang række niveauer for social status, hvor der kun findes få medborgere på hvert niveau. Derimod illustrerer den horisontale model, at de fleste medborgere findes på det mellemste niveau ud af ganske få niveauer. Princippet er, at i den vertikale model er der 
højt at flyve og dybt at falde; men det sker sjældent. Den er kendetegnet ved en statisk orden, hvor alle medborgere har forudbestemte positioner. I den horisontale model er der i princippet ingen forudbestemthed, og mobilitet er mulig men begrænset af de få niveauer. Her kan medborgeren hverken stige særligt højt til vejrs eller synke særligt dybt.

Selvom Asplunds analyse befinder sig på tankefigurernes niveau, kan han alligevel ikke nære sig for at henvise til historiske forhold. Med klædedragtens tidligere forskrifter, hvori beskæftigelse, rang, $k \varnothing n$ og nationalitet direkte kunne aflæses, illustrerer han den vertikale orden i det forhold, at alle positioner i samfundet er optagede, og ingen position kan indtages af mere end en person samtidig med, at den position, man har, er ens rette og nødvendige position (132-33). I en sådan samfundsorden er enhver form for konkurrence umuliggjort og dermed også den specielle konkurrenceform, der betegnes som mimetisk rivalitet. Man har kun det tøj, der svarer til ens fag og sociale rang. Hvis man i denne orden forsøger at imitere andre, vil det fremstå som et fors $\emptyset \mathrm{g}$ på at erobre en position, som ikke tilkommer én. Person smelter per definition sammen med position, og der findes ingen sideordnede positioner.

I slutningen af 1800-tallet i Frankrigs tredje republik var den vertikale katedral nedsmeltet og flød ud til siderne, og Asplund henter her slående eksempler på mimetisk rivalitet (134ff). I dette historiske landskab placerer Asplund baron Pierre de Coubertin som en entusiast præget af en svunden samfundsordens ideal og tankemåde men alligevel ikke bagstræberisk i sin erkendelse af, at taleret, fri konkurrence, præstationsmotiv, selvrealisering var kommet for at blive. Han ville gerne udrette noget i sin frustration men var ikke et lit- terært geni som Zola, et akademisk geni som Durkheim eller et politisk geni som Clemenceau. Inspireret af antikkens Grækenland og det engelske kostskole-miljø, specielt Rugby School, kunne han i den olympiske idé kombinere sin respekt for demokratiet med sin aristokratiske baggrund.

Hermed er Asplund startet på sin indkredsning af den sociale opfindelse, Pierre de Coubertin og hans fæller lancerede. Opfindelsen består $\mathrm{i}$ at kombinere to samfundsordener. De Olympiske Lege og også nationale og lokale konkurrencer sikrer en bestemt rangorden. Alle positioner skal besættes, såvel de højeste i olympiske konkurrencer som de laveste i lokale konkurrencer. Ingen uafgjorthed accepteres, og enhver må gøre sit bedste, så de rette placeringer kan foretages. I denne orden afspejles den vertikale, stivnede katedral. Denne orden er imidlertid ikke permanent. Excellence-ordenen er momentan, en forestilling, som ikke eksisterede nogle århundreder før den moderne sports opkomst, hvorfor Asplund kan fastslå en anledning til, at sporten ikke opstod på eksempelvis Ludvig d. XIV's tid (141). I en tidligere samfundsorden var konkurrence umuliggjort, og ordenen kunne karakteriseres ved en forudbestemt klarhed og vished. I den moderne konkurrencesport er udgangspunktet uklarhed og uvished, hvor selve konkurrencebegivenheden skaber klarheden og visheden - for en stund (142). Det er netop denne dynamiske excellenceorden, der ifølge Asplund gør sportskonkurrencen fascinerende.

Den moderne sport udgør et paradoks. Asplund formulerer paradokset ved, at sporten med et moderne middel, konkurrencen, vil virkeliggøre et gammelt ideal og en svunden orden: en klar og tydelig excellenceorden (144). Således finder han 
det ikke tilfældigt, at initiativet til de moderne Olympiske Lege var taget af et aristokrati med frarøvede privilegier, støttet af en lille kreds af prinser, generaler, professorer og millionærer, en slags »överflödig herrklubb« (145). Hvem skulle ellers have råd, tid og lejlighed til at hellige sig et så stort og idealistisk projekt?

Den orden d'herrer formåede at skabe med den rendyrkede konkurrenceform, anser Asplund som en mindre væsentlig pointe end den, at de med deres initiativ fandt på en måde at ophæve den mimetiske rivalitet på. I den mimetiske krise bliver målet for menneskelig stræben udvisket. Et sådant problem løser den moderne konkurrencesport med sit entydige mål: at blive bedst i verden (eller i serie 4) og hyldet af store (eller mindre) tilskuermasser. $\mathrm{Og}$ målet var bredt ud til at bare det at deltage, og ikke nødvendigvis at sejre, i De Olympiske Lege var og stadigvæk er ærefuldt.

Pierre de Coubertin fandt i sporten et dynamisk og demokratisk middel, som på $\sin$ vis er enestående. Dynamisk i bestræbelsen på rekordforbedringer og demokratisk i kraft af, at lighed var udgangspunktet. Resultatet var ulighed men en efter Coubertins opfattelse retfærdig ulighed. Ydermere en forbigående ulighed, der ikke skaber fjendskab, som uretfærdige uligheder gør det i samfundet.

Sportens ridderlige form for konkurrence, som var opbygget omkring den idé, Pierre de Coubertin omtalte som esprit chevaleresque, kombinerede et feudalt og et demokratisk ideal. Denne ridderlighed er imidlertid, som Asplund nævner (150), og som historien har vist, ikke fri for dopingskandaler og politiske udnyttelser af de store konkurrencer og deres deltagere. Idéen om »det rene spil« må fastholdes, hvis sportens grundlag, som redegjort for her, ikke skal udviskes. Asplunds opstilling af sport og mimetisk rivalitet som et dialektisk begrebspar falder til jorden, hvis sport bliver en såkaldt »smudsig « konkurrenceform, som den mimetiske rivalitet kan betegnes som.

I modsætningsparret mimetisk rivalitet og ridderlig konkurrence finder Asplund nøglen til den olympiske bevægelse og den moderne konkurrencesports succes. Utopien blev også succesrig i kraft af sin begrænsning (156). Modsat mange andre utopier var der ikke tale om at reformere et helt samfund men om at tage fat i en enkelt sag: den frivillige fysiske anstrengelse. Denne anstrengelse blev organiseret, regelsat og ritualiseret men også isoleret i tid og rum. Sporten udgjorde en verden for sig og var i princippet ikke indskrevet i samfundsmæssige forhold vedrørende race, $\emptyset$ konomi og politik. Når sportsmanden skulle indtræde på stadion, blev hans civile status sat i parentes.

Asplund kalder sporten for et reservat $\mathrm{i}$ samfundet, hvor rangskalaerne i hhv. samfunds- og sportssfæren i princippet kan være uafhængige af hinanden. Således formår sporten næppe heller at få en indflydelse på samfundet i form af den internationale forbrødring, Pierre de Coubertin forestillede sig, eller at afskaffe eller udligne forskelle mellem sociale klasser eller for den sags skyld fjerne den mimetiske rivalitet.

» - men den förmår ge oss en viss respit.«(157)

Sporten har ændret sig siden 1896-1912 men ikke til ukendelighed. Trods kommercialisering og mediebevågenhed er sportens idé, som den her er skitseret, stadig mulig at udskille i den aktuelle konkurrencesport. Denne sportens grundlæggende idé og ikke mindst betingelserne for den 
moderne sports opkomst, anskuet ved begrebet om den mimetiske rivalitet og excellenceordenen, kan udgøre et teoretisk afsæt for analyser af aktuelle betingelser for sportsudøvere i dag. Den dynamiske excellenceorden, som kendetegner moderne konkurrencesport, er sandsynligvis af stor betydning for rekrutteringen til sport ikke kun på eliteniveau og ikke kun blandt mænd. Endvidere viser det sig, at betydningen af sportens kombination af frihed og orden, som sportens idé grundlæggende bygger på, er intakt i elitesportsudøveres kulturelle praksis hundrede år efter. ${ }^{6}$

\section{Frirum fra kфnskampe}

Fortolkningen af den moderne sport som et frirum fra den såkaldte mimetiske rivalitet kan viderefortolkes i et kønsperspektiv ved at anskue den moderne sport i slutningen af 1800-tallet som et frirum ikke kun fra kampe om politiske og klassemæssige positioner, men også for kampe om kønspositioner. $^{7}$

Den Internationale Olympiske Komité (IOC), som selv udpegede og stadigvæk selv udpeger sine medlemmer, var på daværende tidspunkt renset for kvinder. De moderne Olympiske Lege var de første tiår kun åbne for relativt få aktive kvinder, der deltog $\mathrm{i}$ opvisninger snarere end i deciderede konkurrencer. Først i løbet af 1920'erne blev udvalgte, målelige konkurrencediscipliner gradvist tilgængelige for kvindelige sportsdeltagere.

Den tidlige moderne sport kan i sit udgangspunkt anskues som et frirum for mænd. Set i et samfundsmæssigt perspektiv kunne sporten måske også som sådan ses som en løsning på et væld af kønsmæssige uvisheder, der netop opstod i slutningen af 1800-tallet og i begyndelsen af 1900-tallet.
Kvinders samfundsmæssige fremtrængen i perioden omkring initiativet til etableringen af de moderne Olympiske Lege har antageligt haft en væsentlig betydning, hvis vi forsøgsvist ser den moderne sport som et frirum fra kønskampe om positioner. Den mimetiske rivalitet, Asplund påpegede, havde udspillet sig i det vestlige Europa i det 18. og 19. århundrede med en række eksempler på politiske revolutioner og rævekager i Frankrig, udspillede sig også $\mathrm{i}$ en begyndende kønskamp. De engelske suffragetter er bare ét slående eksempel. Initiativet til de moderne Olympiske Lege vil i dette perspektiv fors $\varnothing$ gsvist blive set også som en reaktion på en spirende, moderne kvindelighed. ${ }^{8}$

Med den moderne sport betragtet som en social opfindelse blev der skabt et rum ved siden af samfundet. Et rum, der kunne holde kønnene adskilt i modsætning til samfundsmæssige sfærer, der med moderniteten problematiserer $k \emptyset n$, således at de fleste rum i princippet kan indtages af såvel kvinder som mænd. En etablering af moderne sport som fysiske og funktionsmæssige grænser mellem mande- og kvindekroppe kan således ses i lyset af forekomsten af usikkerhed omkring $\mathrm{k} \varnothing \mathrm{n}$ nenes positioner.

Netop i slutningen af 1800-tallet er der i den nordvestlige verden en række historiske begivenheder og forandringer i den sociale levevis, der understreger, at kvinder og mænds positioner ikke længere var selvskrevne. Kvindesagsforkæmperne var få og havde på ingen måde deres eget køns fulde opbakning. Alligevel sættes der adskillige historiske milepæle for ændringer i kvinders sociale forhold, tilnærmet mænds, i slutningen af 1800-tallet og i begyndelsen af 1900-tallet. Der var tale om en begyndende juridisk og politisk ligestilling samtidig med individuelle og litterære 
kvindeoprør rundt omkring i den nordvestlige verden. I Danmark stiftedes Dansk Kvindesamfund i 1871 med henblik på at forbedre kvinders vilkår på arbejdsmarkedet samt at ligestille dem med mændene i ægteskabet. Senere beskæftigede Dansk Kvindesamfund sig også med spørgsmålet om valgbarhed og valgret og var primus motor for indførelsen af kvinders valgret til rigsdagen i $1915 .{ }^{9}$

En opløsning af retten til bestemte positioner kønnene imellem kan kun forstærke den mimetiske krise, vi har set, det olympiske initiativ kunne være en løsning på. Kunne modellen også løse en begyndende uorden i den hidtidige kønsorden?

\section{De mandige karakterer}

Pierre de Coubertin afholdt sig, som bekendt, ikke fra at eksplicitere den rolle, han tildelte kvinderne i sit initiativ:

»I personally am against the participation of women in public competitions, which does not mean that they should not participate in sports, yet not in public. At the Olympic Games their primary role should be like in the ancient tournaments - the crowning of the (male) victors with laurels. $\ll^{10}$

Vel netop som et udslag af en mimetisk rivalitet mellem kvinder og mænd i visse befolkningslag på den tid, fandt en række kvinder sig imidlertid ikke i en sådan passiv position. Især i overklassen, som var repræsenteret i det olympiske initiativ og iøvrigt, som nævnt, dominerede sporten aktivt men også organisatorisk i slutningen af 1800-tallet og begyndelsen af 1900-tallet, skete der en vækst i kvinders lønarbejde uden for hjemmet. Samtidigt fik kvinderne adgang til akademiske uddannelser og kunne gøre sig gældende i det offentlige liv. Kvinders fremfærd, især fra slutningen af 1800-tallet i sfærer tidligere forbeholdt mænd, blev til, hvad den danske kultursociolog og kønsforsker Henning Bech betegner som:

$» \ldots$ et samfundsmæssigt kønsproblem, og således også den periode hvor mandigheden reagerer. $\ll^{11}$

Sportens opkomst og succes samt privilegium for bedrestillede mænd kan ses som en moderne tendens, der også omfatter æstetisering af mandekroppe. »Mand « i moderniteten er ikke længere udelukkende noget, mænd er, men noget mænd har en mulighed for at blive netop ved at spille på $»$ mandigheden $\ll{ }^{12}$

De nævnte samfundsmæssige forandringer omkring århundredeskiftet kan imidlertid give anledning til at antage, at mændene ikke skal dyrke sport udelukkende for at styrke deres mandighed. De skal ydermere dyrke sport for at undgå kvinderne. Idrætshistorikeren Hans Bonde har med bogen Mandighed og sport vist, hvorledes termen mandighed næsten opnår kultstatus i sporten omkring år 1900. Som han skriver:

»... behøver det ikke hænge sammen med, at mandligheden er blevet styrket. Det omvendte, at mændene omkring år 1900 føler sig truede og usikre i deres mandlighed, og derfor opruster deres maskulinitet ved at hylde deres »mandighed«, kan lige så godt være tilfældet. $\ll^{13}$

Hvis kvinderne eller kvindeligheden truer, har en mulig løsning været at holde kvinderne ude fra sportens sfære og til nøds lade dem få adgang, når mændene skulle hædres og bekranses. ${ }^{14}$ 
Pierre de Coubertins intention var i mindre grad at lancere de moderne Olympiske Lege som et forum, hvori mænd kunne blive mandekroppe. Coubertin var meget fokuseret på de fysiske præstationer, mindre med henblik på æstetisering af mandekroppe end med henblik på dannelsen af en bestemt karakter. Således var han også særdeles oprørt, da medierne med deres voksende udbredelse begyndte at gøre sporten spektakular. Hvilke katastrofale konsekvenser kunne dette ikke få? Eksplicit frygtede han for en kommercialisering og politisering af sport. Implicit frygtede han måske, at sådanne tendenser kunne udmønte sig i krav om kvinders mere markante position i sporten. I så fald skulle hans frygt vise sig ikke at være ubegrundet.

Kvinder har på et ret tidligt tidspunkt formået at dyrke sportens glæder på trods af diverse herskende forestillinger om, hvad kvinder kunne og burde give sig $\mathrm{i}$ kast med. I protest mod IOC's udelukkelse af kvinder fra blandt andet atletikkens discipliner arrangerede Fédération Sportive Féminine Internationale (FSFI) i Paris i 1922 et særskilt Olympiske Lege for kvinder, Women's World Games, som fortsatte hvert fjerde år til og med $1934 .{ }^{15}$ Efterhånden som historiske kilder bliver fundet frem og fortolket, viser det sig, at kvinder havde egne fora for sportslige udfoldelser, samtidig med at mange mandesportsgrene var konstant truede af kvinders interesse for dog også efterhånden at blive åbnet for kvinders deltagelse. Åbningen kan ses som resultat af både kvinder og mænds kamp for en demokratisering af sportslig deltagelse. Men den kan også ses som tegn på, at privilegier, der tidligere var officielt forbeholdt mænd som et led i moderniseringen, også blev til privilegier, der kunne passe til og skabe den moderne kvinde. ${ }^{16}$
Sport kunne med fordel inddrages som et væsentligt middel i den moderne kvindesocialisation. Og det blev den.

Fra langsomt at blive anerkendt som et middel til at bidrage med sociale kompetencer for den moderne kvinde var der imidlertid langt til, at sporten i offentligheden blev anset for passende som bidragyder med hensyn til kvinders kulturelle kompetencer forstået som måderne at skabe og udstille sit køn på. Der er tale om stadigt igangværende og ikke altid kontinuerlige og kronologiske processer. En tydelig tendens er imidlertid, at sport som en kulturel kompetence for kvinder har en anderledes træghed end sport som en social kompetence. Herom vidner Pierre de Coubertin med fleres udtalelser: at kvinder gerne måtte dyrke sport, bare ikke i offentligheden. På offentlige sportsarenaer, som med mediernes fremvækst er blevet synlige for flere, er der efterhånden skabt forbedrede muligheder for ikke bare at udstille, men også at skabe sit køn.

\section{Det olympiske performance- system}

Hvorledes de moderne Olympiske Lege er en kulturel performance, også med udstilling og skabelse af $k \varnothing n$, vil jeg vise med henvisning til den amerikanske sociolog John MacAloons genreanalyse. Især fremhæver han genren »spectacle« i karakteristikken af legene, som de har udviklet sig i løbet af det 20. århundrede.

Bestemmelsen af legene som et skue var oprindeligt ikke at finde i den olympiske bevægelses selvforståelse men blev betragtet som en genre, der trængte sig ind på sportens festival og ritualer. Idéen med den moderne olympiske begivenhed var, at den skulle være en festival og ikke et »spec- 
tacle «. »Den sande sportsmand « var for Coubertin »den mand, som tilskuerne kun tilfældigvis iagttager ${ }^{17}{ }^{17}$

Genrens betydning er imidlertid vokset frem i takt med legenes popularitet og modernisering. Historisk falder det sammen med kvindernes stadigt voksende deltagerantal indenfor sport fra 1920-30'erne frem til i dag, og jeg vil senere fors $\varnothing$ ge at vise, hvorledes netop denne genre giver plads for nye refleksioner over $k \emptyset n$.

Betegnelsen »spektakulær« blev af de danske journalister Line Baun Danielsen og Morten Stig Christensen fra TV2, men også i den skrevne presse, utallige gange anvendt til at karakterisere legene i Sydney år 2000. Hvad vil det egentlig sige? Og er det en tilstrækkelig karakteristik?

De Olympiske Lege anskuer MacAloon som en kulturel performance, der består af fire forskellige genrer: festival, ritual, spil (game) og skue. De er allesammen genrer, som eksplicit er dukket op i den olympiske historie som karakteristik af De Olympiske Lege. MacAloons bidrag ligger i at karakterisere genrerne, især skuet som ikke i så grundig grad som de $\varnothing$ vrige genrer har været genstand for antropologers og andre fagfolks etnografiske studier. Samtidig viser MacAloon på original vis, at lige meget hvor meget Coubertin søgte at underbetone De Olympiske Lege som et skue, er skuet i kombination med de $\varnothing$ vrige genrer karakteristisk for den appel, De Olympiske Lege har på såvel deltagere som publikum i moderne tid. En så altomfattende appel at der er tale om en jævnligt tilbagevendende verdensbegivenhed, som er eskaleret i status og omfang i forhold til, hvad den var for hundrede år siden.

Pointen med at referere til de olympiske begivenheder som et skue og ikke kun et spil, et ritual eller en festival, som Coubertin understregede, legene skulle være, er således at være i stand til at fortolke de ændringer i legenes status og omfang, der har fundet sted siden 1920-30'erne. Samtidig pointerer MacAloon, at skuets spektakulære kraft ikke står alene i en nuanceret fortolkning af den tiltrækning, De Olympiske Lege formår at drage et voksende antal deltagere og publikum med.

\section{Et skue par excellence}

Vi kender »skue « fra et dyrskue som en opvisning og udstilling af kvæg og landbrugsmaskiner, vi uforpligtende kan kigge på for at trække os tilbage, når vi har fået nok. Vi forventer ikke nødvendigvis, det skal være morsomt eller flot som en cirkusforestilling eller dramatisk som et skuespil. Vi har blot fået muligheden for at beskue »et stykke af virkeligheden «, som i denne specielle anledning er placeret $i$ en form for optræden for os og dermed forekommer storslået i modsætning til en ko på marken.

MacAloon karakteriserer skuet ved fire distinktive træk: ${ }^{18}$

1. Det engelske »spectacle« kommer fra det latinske »specere«, som betyder »at se på« eller fra det indo-europæiske »spek«, som betyder »at observere «. Ordbogsdefinitioner understreger det visuelle og henviser til symbolske koder: noget udstillet, et bemærkelsesværdigt syn, noget der er seværdigt.

2. Kun seværdigheder af en bestemt størrelse og grandiositet kan imidlertid betegnes som et skue. Således kan det være størrelse, proportioner, farve eller andre dramatiske kvaliteter, der i fremvisningen appellerer til et publikum.

3. Der kan kun være tale om et skue, hvis performere og publikum er adskilte fra hinanden og har forskellige roller. Beg- 
ge roller skal være repræsenterede, og de kan ikke være sammenfaldende. Således adskiller skuet sig fra ritualet, som i højere grad appellerer til (pligtfuld) deltagelse og ligefrem devalueres ved distanceret observation. Udefrakommende observatører er ikke en del af strukturen i ritualet, hvorimod de er en strukturel betingelse for skuet. Ritualet er karakteriseret ved pligt, skuet ved valg.

4. Skuet har en dynamisk form, som kræver bevægelse, handling, forandring og udveksling blandt de deltagende på »scenen«, og tilskuerne må til gengæld blive betaget. Således kan vi udelukke landbrugsmaskinerne og henlægge dem til en særlig udstilling på dyrskuet. Vi taler heller ikke om et maskinskue eller et maleriskue eller et skulpturskue, og hvis vi gør, er det i metaforisk forstand.

Disse fire kriterier opfylder De Olympiske Lege i en grad, der gør legene til et skue par excellence og indenfor skue-genren til en typisk case, som andre cases kan sammenlignes med. Den dramatiske karakter, som trækker såvel aktive som tilskuere til, er ikke kun at finde i konkurrencernes dramatiske bevægelser, men er, som MacAloon skriver, »pure movement dramatized « (246), hvilket vi også kender fra andre sportslige begivenheder som eksempelvis det årlige, internationale cykelløb Tour de France.

\section{Ikke kun et skue}

En nærmere karakteristik af skuet opnår MacAloon ved at pointere forskelle til de $\emptyset$ vrige genrer, hvilket jeg kun ganske kort kan berøre her. Eksempelvis kommer »festival « af det latinske »festivus «, som betyder »munter, glad, sorgløs «. Skuet forbin- des derimod ikke med nogen bestemt stemning eller stil udover en diffus undren eller ærefrygt. Snarere vil et bredt følelsesspektrum udfolde sig under skuet, og der kan være uhyggelige skuer, morsomme skuer, flotte skuer etc.

Under festivaler er de deltagendes og tilskuernes roller mindre distinkte end under skuet. Skuet er i den grad forbundet med synet på bekostning af andre former for publikumsdeltagelse. Samtidig kan et skue i modsætning til en festival opstå spontant og lejlighedsvist og er i modsætning til festivalens harmoni, balance og varighed knyttet til maksimet: jo mere eller større des bedre (246).

Festival og skue har nogle indbyggede modsætninger, der på dialektisk vis befinder sig i vor tids største skue: De Olympiske Lege. Legene er i tidernes $1 \varnothing b$ blevet stærkt fremhævet som netop en festival af toppen af den olympiske bevægelse. Coubertin kaldte legene for »a festival of human unity«, og i 1930'erne blev han for alvor bekymret for, at de kunne udvikle sig til $\gg . .$. only theatrical displays, pointless spectacles ... ${ }^{19}$

Håbefulde, potentielle værtsbyer for afholdelse af De Olympiske Lege er opmærksomme på, hvad Coubertin i 1918 formulerede som:

»If anyone were to ask me the formula for 'Olympizing' oneself, I should say to him, 'the first condition is to be joyful'. $\ll^{20}$

Værtsbyerne forsøger at sælge deres koncept med vægt på festival, og de voksende problemer med politiske, $\varnothing$ konomiske og organisatoriske stridigheder s $\varnothing$ ges negligeret eller forebygget.

Indenfor metagenren »festival « er der i den konkrete, olympiske festival iøvrigt pålagt en lang række restriktioner fra 
IOC's side. Restriktioner, der vidner om olympismens adelige rødder og bunder $\mathrm{i}$ forestillinger om »orden, storhed og smag « (250). Skuets tendens til gigantisme søges her formindsket med restriktioner på eksempelvis legenes varighed og hyppighed, kriterier for deltagerantal og for kvinders deltagelse i hvilke sportsdiscipliner samt for optagelse af nye sportsdiscipliner, antallet af konkurrencer, repræsentationer udelukkende ved nationer, streng supervision ved programsættelse, ritualer, ceremonier og sideløbende, kulturelle programmer (250). Karakteristisk for olympismens begrænsninger af overkategorierne festival og skue er, at de er nært knyttet til genrerne ritual og spil.

Ritualet er i følge MacAloon sædvanligvis adskilt fra andre former for ceremoniel aktivitet ved, at ritualet vækker og involverer religiøse eller sakrale kræfter, og at rituelle handlinger virker på - og ikke kun markerer eller følger med - sociale overgange eller spirituelle transformationer (250). Ritualets virkning er baseret på, at det er i stand til sætte deltagerne i direkte og forholdsvist uformidlet kontakt med selve grundstrukturen, som i det olympiske ritual kan siges at være idéen om det menneskelige fællesskab.

I de olympiske ritualer indgår de tre sociale enheder: individet, nationen og menneskeheden. I det lys er det ikke overraskende, at de protester, der har været manifesteret under afholdelsen af De Olympiske Lege, er gået på tværs af disse enheder og har været på baggrund af etniske, racemæssige eller ideologiske konflikter som eksempelvis de sorte amerikaneres black power hilsener i 1968 og 1972. Nationen som en repræsenteret enhed har i Coubertins opfattelse af den »sande internationalisme« ikke været $\mathrm{i}$ modstrid med den internationale fred og forbrødring. Tvært- imod afhænger verdensfreden i Coubertins forstand af lovprisningen af menneskelige forskelle, som de også udspiller sig indenfor nationerne og ikke af en bortradering af disse forskelle. Som Asplund påpegede, formåede olympismen netop med sin kombination af den vertikale og horisontale sociale orden at skabe et fredeligt rum for en bestemmelse af forskelle. Og Coubertins opfattelse var da også, at menneskeheden ikke bestod på trods af, men på grund af, sociale og kulturelle forskelligheder (252). En væsentlig hemmelighed bag olympismens succes i såvel hierarkiske som egalitære samfund er sandsynligvis netop denne kombination af forskel og lighed, af hierarki og lighedsprincip.

MacAloon viser i sin analyse en historisk transformation af de fire genrers forbundethed i det olympiske performancesystem, som det vil blive for omfattende at komme ind på her. Essensen i transformationen kan forklares ud fra de ændringer, der skete fra og med 1920-30'erne, paradoksalt nok også som en følge af legenes succes. De Olympiske Lege er siden 1930'erne ifølge MacAloons genremodel blevet til et moderne skue par excellence. IOC har blandt andet ved at slække på amatørreglerne for at få så mange nationer som muligt med bidraget til denne udvikling. Sammen med den generelle samfundsudvikling og dens indflydelse på sportens udvikling, i særdeleshed den kommercielle organisering og mediernes indflydelse, fremstiller MacAloon det, at De Olympiske Lege er blevet et skue, som hovedårsagen til nedtoningen af genrerne festival, ritual og game.

\section{Hvorfor dominerer skuet?}

Grænserne mellem det olympiske rum, den olympiske tid og det daglige samfundsliv er med turistbureauer, fjernsynsstationer 
og andre nye, kommercielle institutioner blevet udvisket, og der er ifølge MacAloon sket en generel samfundsmæssig indtrængen i den hellige sport (263). Udformningen af De Olympiske Lege som et skue kan ses som en følge af, at legene som festival og ritual med en fælles sandhed fortoner sig i deltagelsen af næsten 200 forskellige lande med forskellige kulturer, politiske systemer, $\varnothing$ konomiske ressourcer etc. Samtidig trækker skuets underholdende effekt og dets læggen vægt på tilfredsstillelse af blikket mere end af »ånden « deltagerne væk fra festivalen, ritualet og spillet (264).

Meta-kommunikationen i skuet anfører MacAloon som »admire but do not be deceived « (265) eller sagt på en anden måde: det er altsammen storslået, men det er jo bare en forestilling. Skuet er således en refleksiv genre forstået som en genre, der udgår fra en vis skepsis mod, hvad noget giver sig ud for at være. Genren åbner for mange sandheder. Der findes ikke kun én sandhed og måske slet ikke nogen. Skuegenren er dermed med til at sætte spørgsmålstegnene ved de $\varnothing$ vrige genrer.

Performance-systemet er nu på et hyperrefleksivt stadium, pointerer MacAloon (265), hvilket ikke er holdbart for deltagere og publikum, da det underminerer underholdningseffekten og skaber bekymring. For hvad skal vi overhovedet tro på? Enten er der ingen sandhed, eller også er sandheden: »We are all one because we are all game players.« (265)

De Olympiske Leges vedvarende succes får MacAloon til ikke at forlade analysen på, at legene som et skue udelukkende har en undergravende funktion på legene som festival, ritual og som spil. Han opstiller derfor to spørgsmål til videre analyse: hvordan skal en opdukken af forgrenede performance-typer forstås og placeres i kulturhistorien? Hvorfor er det netop skuet og ikke en anden genre, som tilsyneladende har sejret?

Globaliseringstendenser indenfor $\varnothing \mathrm{ko}-$ nomiske transaktioner, handel, energi, forurening, medier, turisme og kultur har velsagtens gjort verden større set med det enkelte menneskes øjne. Jævnlige, fælles aktiviteter på verdensplan foregår imidlertid kun i regi af De Forenede Nationer (FN) og De Olympiske Lege. De Olympiske Lege involverer lidt færre nationer men et langt større publikum gennem sine stemningsfulde ceremonier. MacAloon overvejer, om skuet måske netop er den genre, der bedst er i stand til at reflektere og formidle denne sociale ekspansion, denne udvidelse af ens synsvidde? Og har publikum ikke også behov for dramatiserede forestillingsbilleder af »de andre «, som deler den samme biosfære og politiske $\varnothing$ konomi og sportslige aktivitet (267)? I dette verdensomspændende skue synligg øres en tendens i vores dagligliv til, at vi i stigende omfang må tage verdensudvidelsen $\mathrm{i}$ betragtning.

\section{Skuet som en rekrutterende kraft}

Men det olympiske performance-system er netop karakteriseret ved at være et forgrenet system bestående af en række andre genrer udover skue-genren. Her skal MacAloons påpegning af skuets destruktive effekt på de øvrige genrer ikke undervurderes. Hvor de $\varnothing$ vrige genrer på forskellig vis reducerer afstanden mellem deltager og tilskuer og kræver, at alle tager aktivt del i performancen og på et eller andet plan bifalder symbolerne og det transcendentale grundlag for handlingerne, trækker skuet derimod i modsat retning. Imidlertid anfører MacAloon, at i samfund, hvor individualiteten allerede er fremherskende, og 
hvor tvang til og ansvar for kollektive handlinger er minimerede, og hvor en udpræget foragt for ritualer er fremherskende, kan skuet få en uforudset »positiv « effekt (268). De, som bare kommer for at se eller blive set, for at nyde skuet eller profitere af det, kan måske pludselig opleve, at de bliver fanget ind af en intensitet og en involvering, de på forhånd ville have nægtet var mulig. MacAloon refererer i den forbindelse til egne oplevelser og en række cases, hvoraf jeg blot skal nævne en enkelt udtalelse fra en ung, amerikansk kvinde, som havde arbejdet tre år i IOC's hovedkvarter i Lausanne:

»I just came to work here because I needed a job. All I knew about the Olympics was that they were »the greatest spectacle in sport«, as Jim McKay, the television guy, says. And then everyone around here, well most of them, really laugh about all the Coubertin stuff, world peace and all that. When Munich (OL i 1972) came along, I decided to go over though I didn't feel terribly excited or anything. I was sitting in the Opening Ceremony and I couldn't believe it. When the torchbearer came into the stadium and the crowd roared, I suddenly began to cry. I remember thinking, »So this is what it's all about! I don't think I'll ever forget that moment as long as I live.«(268)

Under åbningen af De Olympiske Lege år 2000 i Sydney måtte selv den danske og distancerede håndboldspiller Camilla Andersen overgive sig til ritualerne og festivalen inden sporten og spillet for alvor kunne gå i gang. Udtalelser umiddelbart efter åbningen fra deltagende udøvere demonstrerer en overvældethed, der kun findes halvkvalte ord for. Sportsfolk og publi- kum er tydeligvis ikke udelukkende iagttagere af åbningens storslåethed, pomp og pragt. De involveres mere eller mindre frivilligt i noget, der ikke kun kan betegnes ved æstetiske udtryk.

Den amerikanske kvindes udtalelse samt Camilla Andersens TV-transmitterede målløshed demonstrerer, hvorledes en involvering i skuet kan være en rekrutterende kraft til festivalen, ritualet og spillet. Underst $\varnothing \mathrm{t}-$ tet af en række andre cases tilføjer MacAloon en »meta-besked « til skue-genren: »all you have to do is watch«, hvilket gør det muligt for individer at være frie til andet og mere end blot at beskue.

MacAloon søger generelt at karakterisere det moderne ikke ved en opdukken af nye, hidtil ukendte, enkelte, kulturelle performance-genrer, men netop ved en fremkomst af forgrenede performance-typer sammensat af kendte, kulturelle genrer. Her altså eksemplificeret i De Olympiske Lege ved den historiske dynamik mellem de signifikante genrer: skuet, festivalen, ritualet, spillet.

Stadigvæk mangler MacAloon at besvare, hvorfor det netop er skue-genren og ikke eksempelvis festival-genren, der som meta-genre fremmer forbindelsen mellem de $\varnothing$ vrige genrer i den olympiske historie. Hertil svarer han, at festivalen med sit krav om morskab som ramme ikke formår at inkorporere de bedrøvelige, tragiske og fremmedgørende begivenheder, som også har været en del af de olympiske erfaringer. Skuet, derimod, lægger ikke an til andre følelser end undren eller ærefrygt. Festivalen kræver engageret deltagelse og helst passioneret adfærd, hvor skuet kanaliserer adfærden over i distanceret observation. Skuet appellerer ifølge MacAloon til udbredte, moderne værdier ved at vægte synet og overlade resten af oplevelsen til »dialogen« mellem observatøren og det, 
der er set, og således åbne for frivilligheden og det individuelle valg. Samtidig giver De Olympiske Lege som verdensprojekt ved at være et skue mulighed for TVtransmissioner på mere oplagt vis, end en festival kunne gøre (269-70).

Skuet implicerer imidlertid ikke kun distance og valgmulighed men også tvivl, skepticisme, refleksivitet, moralsk uklarhed og ambivalens (270). Skuets etymologi og skuets historie viser, at denne genre producerer og indeholder forestillingsbilleder. Endvidere vedrører skuet som kulturudtryk relationen mellem forestillingsbilleder, realitet, fænomen og væren.

I en diskussion af bidrag til hvad der karakteriserer »moderniteten $\ll(270-73)$, argumenterer MacAloon for det nærliggende $i$ at se skuet som en nyere, kulturel performance-genre, der kan skabe en form for orden i den moderne uorden i modernitetens problematiserede forhold til »reality«. Denne orden giver - hundrede år efter den af Asplund påpegede orden $\mathrm{i}$ den tidlige olympiske sport - anledning til en speciel form for forbipasserende kontrol, som er med til at forklare, hvorfor det netop er skuet, der som genre dominerer de populære Olympiske Lege. Som MacAloon formulerer det (275), er der med skuet mulighed for at tage fat i livets »realiteter « og uskadeligg øre dem ved at konvertere dem til optræden eller optrædende, der kan leges med ligesom leget $\varnothing \mathrm{j}$ for derefter at blive kasseret. Men samtidig redder skuet denne »virkelighed « fra at være ren og skær optræden og genpræsenterer den i en udtryksfuld form, så den giver anledning til nye tanker og handlinger.

De Olympiske Lege er et mønstereksempel på denne specielle dobbeltdynamik. Men den forgrenede performance-type genfindes på mindre stadions end det olympiske. Forskellige ritualer udspiller sig blandt fanskarer og i spillernes eller atleternes indtræden på banen, i kåringen af vinderne etc. Med $\varnothing \mathrm{l}$ og horn- eller anden musik og optræden animeres til festival. Spillets uforudsigelige pendlen i lighedens spændingsfelt for at kulminere med en forskel eksisterer på ethvert stadion. Om det er miniput-fodbold eller superliga, er vi uforpligtede tilskuere, der bare skal kigge men alligevel uventet kan få en karruseltur i den forgrenede genremodel.

\section{Skuet som anledning til at reflektere kфnsordenen}

Vi kom fra kvindernes specifikke position $\mathrm{i}$ den tidlige sport til deres begyndende optræden på den offentlige sportsarena, som nu er karakteriseret ved skuet. Selvom termen »kvinder« ikke har været nævnt længe, er vi ikke langt fra den. Nærliggende er det nemlig at placere de moderne sportskvinder i den ovennævnte dobbeltdynamik. På den offentlige sportsarena er kvinderne ikke et hvilket som helst udstillingsinventar, der pilles ned af scenen igen og lever videre som de græssende køer eller et andet rent biologisk væsen. De bliver uden tvivl genstand for nye tanker og handling$\mathrm{er}$, såvel egne tanker og handlinger som publikums.

Kvindernes plads i den olympiske sport kan legitimeres i den olympiske idé ved, at tankerne om verdensforbrødringen efterhånden blev en metafor, og bredere termer for menneskeheden, der også omfattede søstrene, vandt frem. Den olympiske bevægelses skepsis overfor legene som et skue kan, ud fra MacAloons karakteristik af skuet som et moderne symptom, ses som et anti-moderne træk, der indbefattede en social bekymring over, at ikke kun mændenes mandighed, men også kvindernes 
kvindelighed hermed blev et anliggende for refleksivitet: er kvinder virkelig i stand til at gøre sådan? Og kan de se sådan ud -i klæder, krop og tilstand? Kan de også blive gravide og føde børn og fortsætte sporten derefter? ${ }^{21}$

Sporten som skue bekræfter imidlertid stadigvæk menneskeheden i, at mænd springer og kaster længere og løber hurtigere end kvinder. Selvom der efterhånden er et utal af kvinder, der kan løbe hurtigere og længere end langt de fleste mænd, er det sandsynligvis ikke det, de fleste ser på et stadion. Men vi kan som moderne individer jo netop selv vælge, hvorledes vi ser og vil reflektere videre over det udsnit af $»$ virkeligheden«, vi præsenteres for på skuet. Deri ligger en væsentlig forklaring på skuet og dermed de moderne Olympiske Leges gennemslagskraft.

\section{Mere end et spejl}

Den moderne sport repræsenterer indenfor en og samme logik de to ellers konkurrerende logikker lighed og forskel. Indenfor lighedens logik etablerer sportens vindtabsystem en måde at håndtere forskel på. Sporten løser ikke kun en ligheds-forskelskonflikt mellem det før-moderne og det moderne, hvilket Asplunds analyse viste. Sporten løser også en spænding $i$ det moderne projekt, hvilket MacAloons analyse synes at vise.

Ligheds-forskelskonflikter kan forekomme uløselige i globaliseringstendensers samtidighed med nationale grænsedragningsfors $\varnothing \mathrm{g}$ samt moderne identiteters formning efter universelle menneskerettighedsprincipper samtidig med deres kønsog klassemæssige, etniske og religiøse tilhørsforhold. Sportens løsningsmodel er således en klar kilde til sportens succes og fascinationskraft.
Den moderne sports begyndende opkomst er blevet tidsfæstet til at være sammenfaldende med den begyndende problematisering af $k \varnothing n$ i slutningen af forrige århundrede. De forhandlinger og mangel på samme, der er foregået i den sportslige sfære omkring kvindernes position, kan naturligvis ikke ses isoleret fra det samfundsmæssige liv iøvrigt. Da kvinderne imidlertid per definition var udelukket fra de sportslige konkurrencer, begyndte de selv at tage affære og arrangerede alternative Olympiske Lege. At kvinderne senere blev lukket ind i sportssfæren som andet end laurbærkranseoverrækkere og opvisningsfigurer skabte orden og enhed i sporten. Det var for rodet, at kvinder dyrkede sporten på deres egen måde - at de på demonstrativ vis måtte vise verden, at de kunne løbe maratonløb eller cykle fra mændene, som da to danske cykelryttere, Johanne Jørgensen og Susanne Lindberg, i 1890'erne slog en række mandlige cykelløbsrekorder.

Kvinderne behøvede som organiserede sportsfolk ikke at virke påfaldende som uofficielle deltagere men kunne som indlemmede i sportens orden i ro og mag konkurrere - vel at mærke mod deres eget køn. Indtil sportens organisatorer blev urolige og kom i tvivl om, om de, der gav sig ud for at være kvinder, nu også i biologisk forstand var kvinder. De lignede ikke kvinder, de gjorde ikke som kvinder, og menstruation og børn kunne de jo ikke få. Kønstesten blev indført for at fjerne den værste tvivl.

I og med at sporten op igennem dette århundrede er blevet mere og mere et skue, har vi skullet se mere og mere på disse flere og flere kvinder, som ikke har holdt sig til klubbernes træningslokaler. Hermed er de indtrådt i den dobbeltdynamik, sportslige konkurrencer i denne artikel er blevet karakteriseret ved: Med sporten som ikke 
kun et spil, et ritual eller en festival, men også et skue, er de kvindelige sportsudøvere konverteret til optrædende. Optrædende kan vi, som MacAloon har påpeget, lege med legetøj for derefter at kassere det. Og alligevel ikke. Skuet er ikke teater men virkelighed. Vi bliver konfronteret med en objektivitet: en benet eller en muskuløs krop, en tidligere skadet eller en aldrig skadet, en fra den lokale sportsklub eller en af de andre, en sort eller en hvid, en kvinde eller en mand. Men det, vi konfronteres med, overskrider i sporten historisk set sig selv, og gør det igen og igen under sportslige begivenheder her og nu. Og en kilde til fascinationen er, at sporten er et ganske særegent performance-system, som kan transcenderes til et symbol på en excellenceorden, der kan lege med livets realiteter.

Hvor den samfundsmæssige uorden sås som anledning til at skabe en anderledes orden i den moderne, olympiske sport $\mathrm{i}$ dens spæde begyndelse, så kan sporten ved i højere grad at være blevet et skue i dag omvendt spille tilbage og udfordre kulturelle forestillinger - blandt andet om køn.

\section{Noter}

1. Præsentationen af de to forfatteres analyser bygger på kapitel 4 og 5 i min ph.d.-afhandling (Pedersen 1998).

2. Den moderne periodes opkomst refererer her til kapitalismens gennembrud i den vestlige verden. Dateringen for dette gennembrud er som bekendt meget omdiskuteret. I store træk vil der være tale om perioden fra omkring midten af 1700-tallet til midten af 1800-tallet, i Danmarks tilfælde i den sene ende af perioden. Moderniteten henviser ikke kun til en bestemt periode men omfatter også holdninger og måder at tænke, føle og handle på.

3. Jeg skal ikke her nærmere redegøre for Girards teoribygning. Ej heller skal jeg systematisk præsentere de af Asplund opstillede præmisser for kritikken af begrebet »mimetisk rivalitet «. For en dybere indsigt $\mathrm{i}$ dette må jeg blot henvise til en læsning af hele bogen Rivaler och syndabockar (Asplund 1989). Det, der forekommer mig relevant at fremhæve i Asplunds analyser, er, hvorledes sportens konkurrenceform adskiller sig fra den mimetiske rivalitets konkurrenceform, idet Asplund med denne distinktion synes at løse en ikke kun historisk gåde men også formår at opstille en model over sportens idé og væsen og karakterisere sport til forskel fra andre kulturelle fænomener. Sidetal i parentes henviser i det følgende til Asplund 1989.

4. Bøje \& Riiskjær i forordet til Coubertin 1996.

5. Asplund nævner 1912 som det årstal, hvor den olympiske bevægelses succes blev endeligt slået fast. Uden at han dog begrunder dette yderligere, skal det ses i lyset af, at De Olympiske Lege indtil

1912 blev afholdt som enkeltstående fænomener. OL i 1900, 1904 og 1908 var således knyttet til en verdensudstilling og blev først i Stockholm 1912 en selvstændig begivenhed (Dansk Idratsliv, bind I, 1995, s. 189).

6. For en konkretisering af dette, se Pedersen 1998, kap. 7-10.

7. Der vil ikke her blive redegjort for en fyldestgørende gennemgang af kønsbegrebet men blot blive rettet en opmærksomhed på sportsudøveres særlige muligheder for måder at forme $k \emptyset n$ på grundet den biologisk bestemte opdeling i henholdsvis kvinder og mænd i sportens rum.

8. At et sådant aspekt er blevet underbetonet i historiske undersøgelser af mandighed i sport, påpeges af Crosset 1990. Se også Bech 1996, s. 36.

9. Disse historiske træk bygger især på Berg, Frost \& Olsen (red.) 1986, s. 209-60.

10. Coubertin 1966, s. 130-34.

11. Bech 1996, s. 36.

12. »Mandighed « anvendes her i samme betydning, som Bonde 1991, s. 12 anvender det, d.v.s. som et værdiladet, positivt udtryk om hankønnets særlige væsenstræk, til forskel fra »mandlig «, som anses for at være mere neutralt. Iflg. Bonde udskiller »mandig « sig først af ordet »mandlig « omkring år 1700, hvilket kan henvise til termens kulturelle betydning: at mænd ikke kun er noget, mænd er, men også noget mænd kan være. For en nærmere redegørelse for begrebet om »æstetisering « og æstetiseringstendensen i moderne samfund, se Bech 1997, især kap. V og VI.

13. Bonde 1991, s. 12. 
14. Jeg skal ikke her bidrage med en gennemgribende, historisk analyse af kvinders positioner i og især udenfor den spirende moderne sport. Jeg har blot skitseret nogle samfundsmæssige tendenser, som ikke nødvendigvis harmonerer med, hvad der var de moderne Olympiske Leges ophavsmænds egne formuleringer omkring den olympiske idé. Flere forhold $\mathrm{i}$ den nordvestlige verden peger imidlertid på en udbredt »maskulinitetskrise« med kvinder som den rivaliserende part (jf. bl.a. Filene 1986 (1974);3-112), og en sådan krise kan sporten ses som en af flere mulige løsninger på (for samtidige reaktioner specifikt overfor kvinders plads i sport, se Pedersen 1998;92 ff). Spejderbevægelsen er et andet eksempel på en sfære, hvor drenge blev oplært i mandighed af mænd, mens pigerne først senere fik deres egne forbund.

15. Hargreaves 1994, s. 211.

16. Mange argumenter blev fremført i relation til den nye tids anderledes krav til kvinder og deres uddannelse. Nogle af disse blev præsenteret af en

\section{Litteratur:}

Asplund, Johan, Rivaler och syndabockar, Göteborg: Bokförlaget Korpen, 1989

Bech, Henning, »Mandslængsel. Hankøn i moderne samfund « I: Dansk Sociologi 7(3), København, 1996, pp. 31-45

Bech, Henning, When Men Meet. Homosexuality and Modernity, Cambridge: Polity Press, 1997

Berg, A.M., Frost, L., Olsen, A. (red.), Kvindfolk. En danmarkshistorie fra 1600 til 1980, I, 1600-1900, København: Gyldendal, 1986

Bonde, Hans, Mandighed og sport, Odense: Odense Universitetsforlag, 1991

Coubertin, Pierre de: The Olympic Idea, Stuttgart: Olympischen Verlag, 1966

Coubertin, Pierre de: Den Olympiske idé. Taler og artikler 1894-1935. Frederiksberg: Det lille Forlag, 1996

Crosset, Todd, »Masculinity, Sexuality, and the Development of Early Modern Sport« I: Messner, M.A. \& Sabo, D.F. (Eds.), Sport, Men, and the Gender Order, Champaign, Illinois: Human Kinetics Books, 1990, pp. 45-54

Dansk idratsliv. Den moderne idrats gennembrud fremadskuende amerikansk pædagog Frances A. Kellor i det amerikanske, klassiske tidsskrift for videnskabelig pædagogik, Education i 1898 (Kellor 1898). Kellor gør i artiklen opmærksom på det kommende århundredeskiftes forpligtelser og udfordringer på det samfundsmæssige plan. Ændringerne med dertil hørende nye krav, mener hun bør afspejle sig i kvindernes dyrkelse af sporten med dens mere tidssvarende karakterdannelse, end de sædvanlige legemsøvelser for kvinder kan bidrage med.

17. Jespersen 1988, s. 25.

18. MacAloon 1984, s. 243-44. Sidetallene i parentes henviser i det følgende til MacAloon 1984.

19. Coubertin, Pierre de 1967: The Olympic Idea: Discourses and Essays, Stuttgart, s. 131. Her citeret fra MacAloon 1984, s. 248.

20. Ibid. s. 57, her citeret fra MacAloon 1984, s. 248.

21. Se Pedersen 1998 for en betragtning af »elitesportsmødre« som et socialt fænomen.

1860-1940, Bind I, af Else Trangbæk (koord.) et al., København: Gyldendal, 1995

Filene, Peter G., Him / Her / Self: Sex Roles in Modern America, London: The John Hopkins University Press, 1986

Hargreaves, Jennifer, Sporting Females. Critical Issues in the History and Sociology of Women's Sports, London: Routledge, 1994

Jespersen, Ejgil, »Sport, Frihed og Lighed. Pierre de Coubertin og olympismen « I: Idratshistorisk Årbog, nr. 4, 1988, pp. 25-37

Kellor, Frances, »A Psychological Basis for Physical Culture« I: Education, 19, 1898, pp. 100-104

MacAloon, John J., »Olympic Games and the Theory of Spectacle in Modern Societies « I: MacAloon, J.J. (Ed.), Rite, Drama, Festival, Spectacle. Rehearsals Toward a Theory of Cultural Performance, Philadelphia: Institute for the Study of Human Issues, 1984, pp. 241-80

Pedersen, Inge Kryger, Den excellente prastation. Elitesport, kvinder og karriere, København: Sociologisk Institut, Ph.d.-afhandling 4, 1998 